\title{
Reproduction and survival of the calanoid copepod Eurytemora affinis fed with toxic and non-toxic cyanobacteria
}

\author{
M. Koski*, J. Engström, M. Viitasalo \\ Tvärminne Zoological Station, 10900 Hanko, Finland
}

\begin{abstract}
Reproduction (egg production and hatching success) and maintenance (mortality and carbon and nitrogen content) of the calanoid copepod Eurytemora affinis were measured at 5 concentrations (ca 50,100,200, 400 and $600 \mu \mathrm{g} \mathrm{Cl}^{-1}$ ) of toxic and non-toxic strains of the cyanobacterium Nodularia sp. and the green alga Brachiomonas submarina, and in 3 different mixtures of these species $(1: 1$, 8:1 and $1: 8$ ). In addition, females with egg-sacs were collected from the sea and exposed to different concentrations of Nodularia sp., to find out whether cyanobacterial exudates disturb hatching of eggs produced in natural food conditions. With the B. submarina diet copepod egg production was high (maximum ca 7 eggs female $\mathrm{e}^{-1} \mathrm{~d}^{-1}$ ), and increased with increasing food concentration, whereas with both toxic and non-toxic Nodularia sp. diet egg production was comparable to that in filtered sea water ( 0 to 2 eggs female ${ }^{-1} \mathrm{~d}^{-1}$ ), irrespective of food concentration. With both toxic and non-toxic Nodularia sp., copepods produced deformed egg-sacs, and hatching success was low, while eggs produced in natural food conditions hatched well, with the exception of those exposed to a high concentration of toxic Nodularia sp. Mortality of $E$. affinis fed with toxic Nodularia sp. was high, whereas high concentrations of non-toxic Nodularia sp. kept copepods alive. No beneficial effects of Nodularia sp. in mixtures with B. submarina were observed. However, mortality in mixtures with toxic Nodularia sp. was low, hatching success generally high and no deformed egg-sacs were produced, which indicated that copepods were able to avoid feeding on toxic algae. Our results suggest that, in addition to its toxic effect, Nodularia sp. lacks certain essential elements needed for copepod reproduction. However, the non-toxic strain is sufficiently high in food quality to sustain maintenance of $E$. affinis, if offered in large quantities.
\end{abstract}

KEY WORDS: Copepod · Cyanobacteria - Eurytemora affinis · Nodulana sp. · Toxicity - Egg production Hatching success - Survival

\section{INTRODUCTION}

Cyanobacteria are generally assumed to be poor food for aquatic crustaceans (Porter \& Orcutt 1980). The negative effects of these may be due to mechanical interference with feeding (Infante \& Abella 1985) or toxic substances (DeMott et al. 1991, Reinikainen et al. 1995). Further, the nutritional value of cyanobacteria is low, for instance, because they contain low amounts of long-chain polyunsaturated fatty acids that are essential for growth of aquatic invertebrates (Ahlgren et al.

-Present address: Department of Ecology and Systematics, Division of Hydrobiology, University of Helsinki, PO Box 17, 00014 Helsinki, Finland.

E-mail: makoski@touko.helsinki.fi
1992, Müller-Navarra 1995). Poor growth and reproduction of crustaceans fed on a cyanobacterial diet has been observed, e.g. by Arnold (1971), Lampert (1981, 1987), Nizan et al. (1986) and Xu \& Burns (1991).

However, certain copepod species feed actively on cyanobacteria (Burns \& Xu 1990a, Burns \& Hegarty 1994), and some species of cyanobacteria have been shown to sustain egg production and growth of copepods (Burns \& Xu 1990b, Xu \& Burns 1991, respectively) and crustaceans (Repka 1996, 1997). Further, increased reproduction is sometimes observed in mixtures of cyanobacteria and other food species (Schmidt \& Jónasdóttir 1997, DeMott 1998, Twombly et al. 1998). These effects may be due to the high energy content and low C:N ratio of cyanobacteria (Burns \& Xu 1990a, Sterner \& Robinson 1994) or the substantial amount of 
certain amino acids (Schmidt \& Jónasdóttir 1997), which may be beneficial for copepods, especially if other food sources with other essential elements are available (Burns \& Hegarty 1994). Thus, cyanobacteria may complement diet if offered in mixtures with other species (DeMott 1998).

Species-and age-specific differences in the response of crustaceans to cyanobacteria are likely to occur (Gilbert 1990, Xu \& Burns 1991). The sensitivity of crustacean zooplankton to harmful or toxic cyanobacteria depends on their ability to select food particles (avoiding cyanobacteria) and on their sensitivity to toxins (DeMott \& Moxter 1991, DeMott et al. 1991, Kirk \& Gilbert 1992). In general, cladocerans are less selective, but also less sensitive, while copepods are often highly sensitive to toxins, but able to avoid ingesting toxic cells (DeMott \& Moxter 1991, DeMott et al. 1991). Further, different species and development stages have different nutritional requirements (Xu \& Burns 1991), and different nutritional qualities are needed for reproduction, growth and maintenance (Sterner \& Robinson 1994). These factors are likely to make responses of zooplankton to cyanobacteria speciesspecific and complicated (Turner \& Tester 1997).

Most of the previous studies on zooplanktoncyanobacterium interactions have been made in fresh water, with cladocerans and cyanobacterial taxa such as Microcystis, Anabaena and Oscillatoria. However, cyanobacteria are also typical for certain brackish water areas and enclosed seas (Richardson 1997, Sellner 1997). In the Baltic Sea, blooms of the cyanobacteria Nodularia sp. and Aphanizomenon flos-aquae are common in late summer and autumn (Kononen et al. 1996), when the highest mesozooplankton biomass and production also occur (Viitasalo et al. 1995, Koski et al. 1999). Most of the Nodularia sp. strains isolated from the Baltic are hepatotoxic, containing the cyclic pentapeptide nodularin, while blooms dominated by A. flos-aquae are generally not toxic (Sivonen et al. 1989). Toxicity of blooms may also fluctuate rapidly (Carmichael \& Gorham 1981), due to, for example, changing environmental conditions (Rapala et al. 1993).

According to previous studies conducted in the Baltic Sea (Sellner et al. 1994, 1996) copepod ingestion and egg production rates were strongly reduced during cyanobacterial blooms. However, it was not clear if copepods suffered from toxic substances or were simply not able to gather enough high-quality food to reproduce. We investigated this by offering the calanoid copepod Eurytemora affinis both toxic (nodularin producing) and non-toxic strains of the cyanobacterium Nodularia sp. and measuring their effect on copepod reproduction (egg production and hatching success) and maintenance (survival and C:N content). The aims of the study were to reveal (1) if copepods are able either to reproduce or to survive on a Nodularia sp. diet, (2) if the negative effects of Nodularia sp. are due to toxicity or poor nutritional quality and (3) if Nodularia sp. can supplement the diet if mixed with other food sources.

\section{MATERIAL AND METHODS}

Algae. Experiments were conducted with the green alga Brachiomonas submarina and 2 different strains of the cyanobacterium Nodularia sp., cultured in aerated batch cultures of ca $3 \mathrm{l}$, at $18^{\circ} \mathrm{C}$ and in an $18 \mathrm{~h}$ light: 6 h dark cycle. $B$. submarina culture was obtained from the culture collection of $S$. and $G$. Hällfors at Tvärminne Zoological Station (Hällfors \& Hällfors 1992). The 2 Nodularia sp. strains were isolated from the Baltic Sea (Lehtimäki et al. 1994) and belonged to the culture collection of K. Sivonen (Department of Applied Chemistry and Microbiology, University of Helsinki). Tv2 medium (Hällfors \& Hällfors 1992) and modified Z8 medium (Lehtimäki et al. 1994) were used as culture media for $B$. submarina and Nodularia sp., respectively. The nodularin content in the toxic Nodularia sp. strain (HKVV) was $0.58 \pm 0.566 \mu \mathrm{g} \mathrm{mg^{-1 }}$ dry $\mathrm{wt}^{-1}$, whereas the other strain (HEM) did not contain any nodularin. The Nodularia sp. strain which did not produce nodularin is referred to as non-toxic, and the one which produced nodularin, as toxic, irrespective of other possibly toxic substances which they may produce. All cultures were unialgal but not free of bacteria.

The cell volume and concentration of Brachiomonas submarina in cultures were estimated with an ELZONE electronic particle counter (Particle Data Inc.) before each experiment. To achieve the right food concentration for experiments, the average carbon content of $B$. submarina cells was estimated from the measured average volume of $257 \mu \mathrm{m}^{3}$ and carbon-to-volume regression of Montagnes et al. (1994) (27 pg C cell ${ }^{-1}$ ). Cyanobacterial concentrations were determined spectrophotometrically using a calibration curve of extinction versus carbon concentration, which was derived from chemical oxygen-demand measurements (Gulati et al. 1991).

Copepods. All experiments were conducted with a calanoid copepod Eurytemora affinis (Poppe) collected from an open archipelago area on the SW coast of Finland. Copepods were collected with a $200 \mu \mathrm{m}$ plankton net, with a single haul from near the bottom to the surface, carefully spooled to $30 \mathrm{l}$ containers together with water from near the bottom and directly transported to the laboratory. Carbon and nitrogen content of the freshly collected females were measured from 3 replicate samples (ca 10 ind. sample ${ }^{-1}$ ), with a stable isotope analyser (RoboPrep-TracerMass ANCA-MS), after drying for $24 \mathrm{~h}$ at $60^{\circ} \mathrm{C}$ in the oven. 
Table 1 Starting date of the experiments, alga species and concentrations used, number of replicates (n), average carbon content of copepods (Eurytemora affinis) in the field at the beginning of each experiment ( $\mu \mathrm{g} \mathrm{C}$ ind ${ }^{-1}$ ), and average egg production ( $\mathrm{Ep}$ ) in filtered sea water control of each experiment (eggs female ${ }^{-1} \mathrm{~d}^{-1}$ ). (FW: filtered sea water; $\mathrm{N}$ : non-toxic Nodularia sp.; Nt: toxic Nodularia sp.; Br: Brachiomonas submarina.) Female carbon content or egg production which is significantly different (Tukey HSD; $\mathrm{p}<0.05$ ) from values in other experiments. Means \pm standard deviations are denoted

\begin{tabular}{|c|c|c|c|c|c|}
\hline \multirow[t]{2}{*}{ Date } & \multicolumn{3}{|c|}{ Experiment } & \multicolumn{2}{|c|}{ Copepod $\longrightarrow$} \\
\hline & Algae & Conc. & $\mathrm{n}$ & Carbon & Ep in FW \\
\hline \multirow[t]{3}{*}{23 Jun } & FW & 0 & 2 & \multirow[t]{3}{*}{$1.8 \pm 0.3^{\circ}$} & \multirow[t]{3}{*}{$0.5 \pm 0.2$} \\
\hline & $\mathrm{N}$ & $50-600$ & 2 & & \\
\hline & Nt & $50-600$ & 2 & & \\
\hline \multirow{6}{*}{$1 \mathrm{Jul}$} & FW & 0 & 2 & \multirow{6}{*}{$3.5 \pm 0.5$} & \multirow{6}{*}{$2.1 \pm 1.1$} \\
\hline & $\mathrm{Br}$ & $50-600$ & 2 & & \\
\hline & $\mathrm{Br}+\mathrm{N}$ & $200+200$ & 3 & & \\
\hline & $\mathrm{Br}+\mathrm{Nt}$ & $200+200$ & 3 & & \\
\hline & $\mathrm{Br}+\mathrm{N}$ & $400+50$ & 2 & & \\
\hline & $\mathrm{Br}+\mathrm{Nt}$ & $400+50$ & 3 & & \\
\hline \multirow[t]{6}{*}{$7 \mathrm{Jul}$} & FW & 0 & 2 & \multirow[t]{6}{*}{$3.6 \pm 0.3$} & \multirow[t]{6}{*}{$5.1 \pm 2.2^{\circ}$} \\
\hline & $\mathrm{Br}$ & $50-600$ & 1 & & \\
\hline & $\mathrm{N}$ & $50-600$ & 1 & & \\
\hline & Nt & $50-600$ & 1 & & \\
\hline & $\mathrm{Br}+\mathrm{N}$ & $50+400$ & 3 & & \\
\hline & $\mathrm{Br}+\mathrm{Nt}$ & $50+400$ & 3 & & \\
\hline \multirow[t]{6}{*}{21 Aug } & FW & 0 & 2 & \multirow[t]{6}{*}{$3.0 \pm 0.2$} & \multirow[t]{6}{*}{$1.6 \pm 1.4$} \\
\hline & $\mathrm{Br}$ & $50,200,400$ & 2 & & \\
\hline & $\mathrm{N}$ & $50,200,400$ & 2 & & \\
\hline & $\mathrm{Nt}$ & $50,200,400$ & 2 & & \\
\hline & $\mathrm{Br}+\mathrm{N}$ & $200+200$ & 3 & & \\
\hline & $\mathrm{Br}+\mathrm{Nt}$ & $200+200$ & 3 & & \\
\hline
\end{tabular}

Experiments were conducted at 4 different time periods from June to August 1998 (Table 1), and the copepads used in experiments were thus likely to belong to different generations. The copepods used in the first experiment were significantly smaller (in carbon content) than copepods used in later experiments (Tukey HSD; $p<0.05$ ). Further, copepods used in the 3rd experiment produced significantly more eggs in filtered sea water (Tukey HSD; $\mathrm{p}<0.05$ ) than copepods in the other experiments. However, despite the differences in egg production rate between copepod generations, the relative response of copepods to food species remained the same with every generation (e.g egg production was always low with Nodularia sp. diet).

Experiments. Egg production, hatching success, mortality and carbon and nitrogen content of Eurytemora affinis were measured at 5 concentrations (ca 50, 100, 200, 400 and $600 \mu \mathrm{g} \mathrm{C} \mathrm{Cl}^{-1}$ ) of Brachiomonas submarina and toxic and non-toxic Nodularia sp., and at 3 different mixtures of $B$. submarina offered together with either toxic or non-toxic Nodularia sp. (1:1: ca 200 $+200 \mu \mathrm{g} \mathrm{Cl}^{-1}$ of each alga, 8:1:400 $\mathrm{ug} \mathrm{Cl}^{-1}$ of B. sub- marina $+50 \mu \mathrm{g} \mathrm{Cl}^{-1}$ of Nodularia sp. and 1:8: $50 \mu \mathrm{g} \mathrm{C}$ $\mathrm{l}^{-1}$ of $B$. submarina $+400 \mu \mathrm{g} \mathrm{Cl}^{-1}$ of Nodularia sp.). In addition, hatching success of eggs produced in natural food conditions in the sampling area, and directly exposed to 3 different concentrations $(50,200$ and $400 \mu \mathrm{g}\left(\mathrm{l}^{-1}\right.$ ) of $B$. submarina or toxic or non-toxic Nodularia sp., was analysed, to reveal possible effects of phytoplankton exudates on the hatching of eggs. Replicate experiments ( 2 to 5 ) were conducted with every diet. Since several copepod generations were used in experiments, a $0.2 \mu \mathrm{m}$ filtered sea water control was included in every series of experiments. Due to differences in the egg production rate between copepod generations (cf. Table 1), egg production was also considered as a percentage of the egg production in filtered sea water in the corresponding experiment.

For the egg production experiments, females with or without egg-sacs were picked with a small amount of water and transferred to filtered sea water for ca $24 \mathrm{~h}$ to adapt to the experimental temperature $\left(13^{\circ} \mathrm{C}\right)$. Afterwards, females were placed into $1.15 \mathrm{l}$ bottles (ca 10 females bottle ${ }^{-1}$ ) containing the desired food solution, and actuated with a plankton-wheel at a turning speed of ca 1 round min $^{-1}$. After a 24 to 48 h adaptation period, females were carefully filtered onto a $200 \mu \mathrm{m}$ net to remove phytoplankton, eggs and nauplii, and changed to a new food solution to start the experiment. After $48 \mathrm{~h}$, females and eggs were filtered onto a $50 \mu \mathrm{m}$ net, and eggs and dead individuals were counted. Egg production was estimated according to

$$
P=N_{\mathrm{e}} /\left(N_{\mathrm{f}} D\right)
$$

where $P$ is the egg production (eggs female ${ }^{-1} \mathrm{~d}^{-1}$ ), $N_{e}$ is the number of eggs at the end of the experiment, $N_{\mathrm{f}}$ is the number of females and $D$ is the development time of eggs (in days). Development time of eggs at $13^{\circ} \mathrm{C}$ was assumed to be $2.2 \mathrm{~d}$ (Andersen \& Nielsen 1997). Half of the females with egg-sacs were placed in petri dishes with filtered sea water and left at $13^{\circ} \mathrm{C}$ for ca $5 \mathrm{~d}$ after which the number of nauplii was counted. In experiments where a only few eggs were produced, several replicates were combined to achieve $>15$ eggs per hatching experiment. Remaining females were prepared for $\mathrm{C}: \mathrm{N}$ analyses as described before. In order to obtain at least 2 replicate $C: N$ analyses per treatment, females from 50 and $100 \mu \mathrm{g} \mathrm{C}^{-1}$ and 400

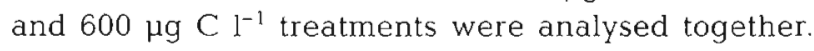
No C:N analyses were obtained in mixture experiments.

For the additional hatching experiment, females with egg-sacs were collected from the sampling area as described before, and placed directly into $1.15 \mathrm{l}$ bottles containing the experimental food solution. Water in these bottles was renewed daily. After $5 d$ of incubation, females and nauplii were filtered onto a 
50 um net, and eggs and nauplii were counted. This experiment was conducted simultaneously with the last egg production experiment (21 August; Table 1).

Differences in egg production, hatching success, mortality and carbon and nitrogen content of copepods between treatments were tested with 1-way analyses of variance (ANOVA) with the SYSTAT statistical package (SPSS Inc., Chicago). The effects of food concentration and food species on egg production, hatching success and mortality of copepods were tested separately for each food species $(F W+5$ food concen-
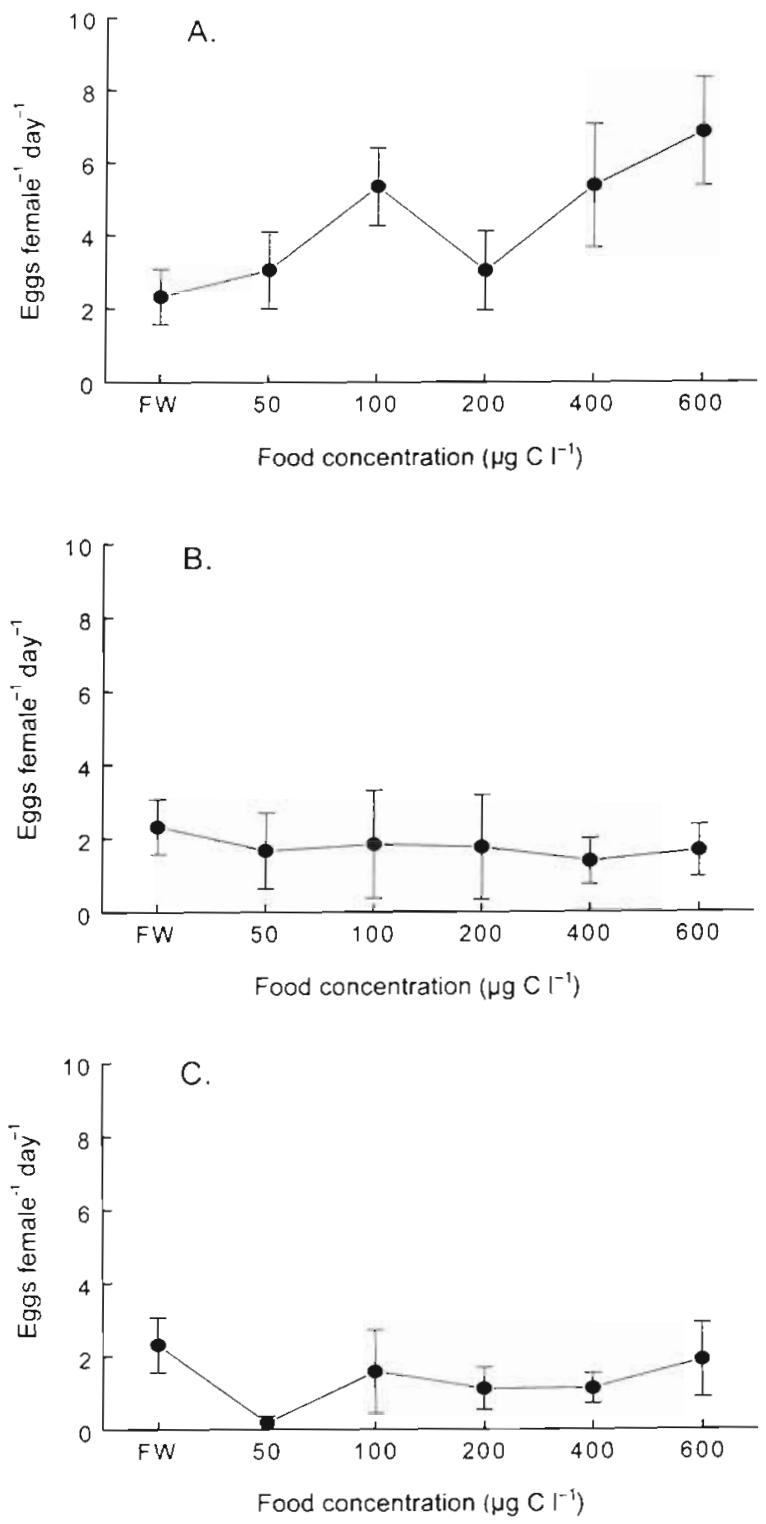

Fig. 1. Eurytemora affinis. Mean egg production (eggs fema$\mathrm{le}^{-1} \mathrm{~d}^{-1}$ ) in different concentrations of (A) Brachiomonas submarina, (B) non-toxic Nodularia sp., and (C) toxic Nodularia sp. Data denote means and standard errors; $n=3$ to 5 (FW filtered sea water) trations) and each food concentration ( 3 food species per concentration), respectively. In contrast, the effect of food concentration and species on copepod carbon and nitrogen content and $\mathrm{C}: \mathrm{N}$ ratio was tested together for all treatments. Tukey's a posterion HSD test was used for pairwise comparisons.

\section{RESULTS}

\section{Egg production}

Egg production of Eurytemora affinis with a Brachiomonas submarina diet increased with increasing food concentration, with the exception of unexplained low egg production at the food concentration of $200 \mu \mathrm{g}$ $\mathrm{Cl}^{-1}$ (Fig. 1). Egg production with $B$. submarina was always higher than that in filtered sea water; at the lowest food level (ca $50 \mu \mathrm{g} \mathrm{C} \mathrm{l}^{-1}$ ) egg production corresponded on average to $125 \%$ of the egg production in filtered sea water, while at the highest food level the egg production was ca 3 times higher than in filtered sea water in the corresponding experiment (Table 2).

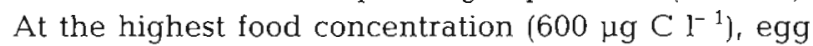
production was in the range of literature values of maximum egg production of sac-spawning copepods (ca 7 eggs female ${ }^{-1} \mathrm{~d}^{-1}$ or ca $8 \%$ of body weight $\mathrm{d}^{-1}$; Kiørboe \& Sabatini 1995) (Table 2), even though higher egg production rates have also been recorded for $E$. affinis (Hirche 1992, Ban 1994). In the same study area the egg production of $E$. affinis in July 1998 was observed to be ca 8 eggs female ${ }^{-1} \mathrm{~d}^{-1}$ (unpubl. data); thus the lower values in the present study indicated

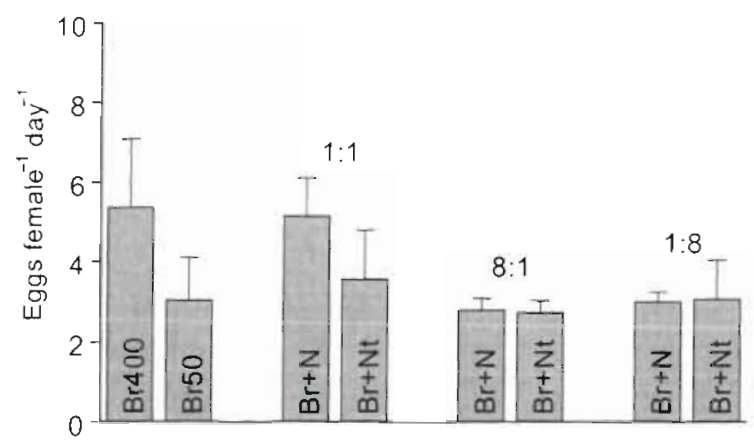

Food mixture

Fig. 2. Eurytemora affinis. Mean egg production (eggs female ${ }^{-1} \mathrm{~d}^{-1}$ ) in mixtures of Brachiomonas submarina ( $\mathrm{Br}$ ) and non-toxic and toxic Nodularia sp. ( $\mathrm{N}$ and $\mathrm{Nt}$, respectively), and with corresponding concentrations (400 and $50 \mu \mathrm{g} \mathrm{Cl}^{-1}$ ) of $B$. submarina as a sole food ( $\mathrm{Br} 400$ and $\mathrm{Br} 50$, respectively). Food concentrations used were: $200+200 \mu \mathrm{g} \mathrm{Cl}^{-1}(1: 1), 400+$ $50 \mu \mathrm{g} \mathrm{Cl}^{-1}(8: 1)$ and $50+400 \mu \mathrm{gCl}^{-1}(1: 8)$ of $B$. submarina and Nodularia sp., respectively. Error-bars denote standard errors; $n=2$ to 6 
Table 2. Eurytemora affinis. Average egg production (as eggs female ${ }^{-1} \mathrm{~d}^{-1}$, as $\%$ of body carbon $\mathrm{d}^{-1}$ and as $\%$ of the egg production in filtered sea water in corresponding experiment), average percentage of temales with deformed egg-sacs (\%), average mortality of females (\%) in experiments with different food species and concentrations and number of replicate experiments (n). The percentage of egg production from that in filtered sea water is calculated separately for each experiment (cf. Table 1); the values presented in the table are the average of these. Means \pm standard deviations are denoted. Abbreviations as in Table 1

\begin{tabular}{|c|c|c|c|c|c|c|c|}
\hline Algae & $\begin{array}{c}\text { Conc. } \\
\left(\mu \mathrm{g} \mathrm{Cl^{-1 }}\right)\end{array}$ & Eggs fem ${ }^{-1} d^{-1}$ & $\begin{array}{l}\text { Egg production } \\
\% \text { body weight }\end{array}$ & $\% \mathrm{FW}$ & $\begin{array}{c}\text { Deformed eggs } \\
(\%)\end{array}$ & $\begin{array}{c}\text { Mortality } \\
(\%)\end{array}$ & $\mathrm{n}$ \\
\hline FW & 0 & $2.3 \pm 2.1$ & $2.9 \pm 2.6$ & & $7.3 \pm 8.9$ & $26 \pm 33$ & 8 \\
\hline \multirow[t]{5}{*}{$\mathrm{Br}$} & 50 & $3.0 \pm 2.4$ & $3.8 \pm 2.9$ & $125 \pm 107$ & $4.2 \pm 5.8$ & $0 \pm 0$ & 5 \\
\hline & 100 & $5.3 \pm 1.9$ & $6.6 \pm 2.3$ & $226 \pm 143$ & $0 \pm 0$ & $0 \pm 0$ & 3 \\
\hline & 200 & $3.0 \pm 2.4$ & $3.8 \pm 3.0$ & $128 \pm 117$ & $0 \pm 0$ & $2.5 \pm 5.6$ & 5 \\
\hline & 400 & $5.4 \pm 3.8$ & $6.7 \pm 4.7$ & $226 \pm 176$ & $0 \pm 0$ & $2.2 \pm 5.0$ & 5 \\
\hline & 600 & $6.9 \pm 2.6$ & $8.5 \pm 3.2$ & $287 \pm 180$ & $0 \pm 0$ & $0 \pm 0$ & 3 \\
\hline \multirow[t]{5}{*}{$\mathrm{N}$} & 50 & $1.7 \pm 2.3$ & $2.0 \pm 2.8$ & $110 \pm 164$ & $13 \pm 11$ & $29 \pm 44$ & 5 \\
\hline & 100 & $1.8 \pm 2.5$ & $2.3 \pm 3.1$ & $81 \pm 75$ & $15 \pm 9.2$ & $20 \pm 19$ & 3 \\
\hline & 200 & $1.8 \pm 3.2$ & $2: 2 \pm 3.9$ & $65 \pm 71$ & $4 \pm 5.5$ & $22 \pm 30$ & 5 \\
\hline & 400 & $1.4 \pm 1.4$ & $1.7 \pm 1.7$ & $145 \pm 256$ & $2 \pm 4.5$ & $6 \pm 8.9$ & 5 \\
\hline & 600 & $1.7 \pm 1.2$ & $2.1 \pm 1.5$ & $208 \pm 276$ & $4.4 \pm 7.7$ & $2.2 \pm 3.9$ & 3 \\
\hline \multirow[t]{5}{*}{$\mathrm{Nt}$} & 50 & $0.2 \pm 0.4$ & $0.2 \pm 0.5$ & $3.6 \pm 8.0$ & $24 \pm 15$ & $72 \pm 45$ & 5 \\
\hline & 100 & $1.6 \pm 2.0$ & $1.9 \pm 2.5$ & $84 \pm 90$ & $8.3 \pm 14$ & $44 \pm 32$ & 3 \\
\hline & 200 & $1.1 \pm 1.3$ & $1.4 \pm 1.6$ & $67 \pm 75$ & $6.7 \pm 15$ & $55 \pm 35$ & 5 \\
\hline & 400 & $1.1 \pm 0.9$ & $1.4 \pm 1.1$ & $152 \pm 186$ & $13 \pm 10$ & $63 \pm 29$ & 5 \\
\hline & 600 & $1.9 \pm 1.8$ & $2.3 \pm 2.2$ & $243 \pm 385$ & $3.7 \pm 6.4$ & $63 \pm 40$ & 3 \\
\hline $\mathrm{Br}+\mathrm{N}$ & $200+200$ & $5.2 \pm 2.3$ & $6.4 \pm 2.9$ & $281 \pm 127$ & $0 \pm 0$ & $0 \pm 0$ & 6 \\
\hline $\mathrm{Br}+\mathrm{Nt}$ & $200+200$ & $3.6 \pm 3.0$ & $4.4 \pm 3.7$ & $183 \pm 139$ & $0 \pm 0$ & $0 \pm 0$ & 6 \\
\hline $\mathrm{Br}+\mathrm{N}$ & $400+50$ & $2.8 \pm 0.4$ & $3.5 \pm 0.5$ & $136 \pm 19$ & $0 \pm 0$ & $0 \pm 0$ & 2 \\
\hline $\mathrm{Br}+\mathrm{Nt}$ & $400+50$ & $2.7 \pm 0.5$ & $3.4 \pm 0.6$ & $133 \pm 23$ & $0 \pm 0$ & $0 \pm 0$ & 3 \\
\hline $\mathrm{Br}+\mathrm{N}$ & $50+400$ & $3.0 \pm 0.4$ & $3.7 \pm 0.5$ & $59 \pm 7.9$ & $0 \pm 0$ & $0 \pm 0$ & 3 \\
\hline $\mathrm{Br}+\mathrm{Nt}$ & $50+400$ & $3.1 \pm 1.7$ & $3.8 \pm 2.1$ & $60 \pm 33$ & $0 \pm 0$ & $13 \pm 23$ & 3 \\
\hline
\end{tabular}

that $B$. submarina may not have been the optimal food for the egg production of E. affinis.

The food concentration did not affect egg production with either non-toxic (1-way ANOVA; df $=5, F=0.126$, $\mathrm{p}>0.05$ ) or toxic (1-way ANOVA; df $=5, F=1.281, \mathrm{p}>$ $0.05)$ Nodularia sp. as food: egg production was not significantly different from that in filtered sea water 10 to 2 eggs female $\mathrm{d}^{-1} \mathrm{~d}^{-1}$ or 0 to $2 \%$ of body carbon $\mathrm{d}^{-1}$ ), irrespective of the toxicity of the strain or food concentration (Fig. 1, Table 2). Further, with both non-toxic and toxic Nodularia sp. as food, egg production was always lower than with the Brachiomonas submarina diet; in high food concentrations (400 to $600 \mu \mathrm{g} \mathrm{C} \mathrm{l}^{-1}$ ) this difference was statistically significant (Tukey HSD; $p<0.05$ )

In mixture experiments egg production varied from 3 to 5 eggs female ${ }^{-1} \mathrm{~d}^{-1}$ ( 3 to $6 \%$ of body weight $\mathrm{d}^{-1}$ ), which was not significantly different from egg production in the corresponding concentration (ca $400 \mu \mathrm{g} \mathrm{l}^{-1}$ ) of Brachiomonas submarina (1-way ANOVA; df $=6$, $F=0.811, \mathrm{p}>0.05$ ) (Fig. 2, Table 2). However, Nodularia sp. still seemed to interfere with egg production in most of the experiments; only in one mixture $(1: 1 \mathrm{~B}$ submarina + non-toxic Nodularia sp.) was the egg production equal to the egg production with $B$. submarina alone. In the 8:1 mixture of $B$. submarina and Nodularia sp. the egg production was lower than that in $400 \mu \mathrm{g} \mathrm{C} \mathrm{I}^{-1}$ of B. submarina alone (Fig. 2), and in the $1: 8$ B. submarina + Nodularia sp. the egg production was $60 \%$ of that in filtered sea water in the same experiment (Table 2), even though comparable to the average egg production with $50 \mu \mathrm{g} \mathrm{Cl}^{-1}$ of $B$. submarina (Fig. 2). This was due to exceptionally high egg production of the copepod generation used in the 1:8 mixture experiment (cf. Table 1).

Eurytemora affinis produced a relatively high percentage of deformed egg-sacs in some of the treatments. These consisted of undeveloped eggs, which were attached together to an undetermined mass, so that the individual eggs could not be separated. Deformed egg-sacs were observed in filtered sea water (ca $7 \%$ of the females with deformed egg-sacs), in low concentrations of non-toxic Nodularia sp. (13 to $15 \%$ ) and in most concentrations of toxic Nodularia sp. (4 to $24 \%$ ) (Table 2 ). The percent of deformed eggsacs in low concentrations of toxic Nodularia sp. was 
significantly higher (Tukey HSD; $\mathrm{p}<0.05$ ) than in other treatments. A few deformed egg-sacs (4\%) were also observed with low concentration of Brachiomonas submarina. In contrast, no deformed egg-sacs were produced in any of the mixture diets.

\section{Hatching success}

Hatching success of eggs produced at Brachiomonas submarina diet was high $(>70 \%)$ in most of the food concentrations, with the exception of the food concentrations of 50 and $200 \mu \mathrm{g} \mathrm{Cl}^{-1}$, where hatching success was low and variable (Table 3 ). Hatching success of the few eggs produced with non-toxic Nodularia sp. was generally low (0 to $42 \%$ ). However, at the 2 highest food concentrations ( 400 and $600 \mu \mathrm{g} \mathrm{Cl}^{-1}$ ) respectively 56 and $87 \%$ of the produced eggs hatched. With the toxic Nodularia sp. diet the hatching success was, in general, significantly lower (Tukey HSD; $p<0.05$ ) than with the other 2 food species, as none of the eggs produced with toxic Nodularia sp. hatched. In food mixtures, hatching success was either comparable or somewhat lower than with a sole $B$. submarina diet. However, hatching success in mixtures was measured only in 1 experiment.

Hatching success of eggs produced in natural food conditions and exposed to experimental food was generally high ( 73 to $100 \%)$, and always higher than that of eggs produced in experiments (Table 3). With high concentrations of toxic Nodularia sp. (200 and $400 \mu \mathrm{C} \mathrm{C} \mathrm{l}^{-1}$ ) this difference was statistically significant (Tukey HSDi $\mathrm{p}<$ 0.05). However, high concentrations of toxic Nodularia sp. seemed to disturb hatching of Eurytemora affinis eggs, irrespective of the food with which they were produced. The hatching success of eggs produced in natural food conditions and exposed to $400 \mu \mathrm{g}$ $\mathrm{C}^{-1}$ of toxic Nodularia sp. was only $36 \%$, which was significantly different (Tukey HSD $i p<0.05$ ) from most other treatments.

\section{Mortality}

Mortality of Eurytemora affinis in experiments with all concentrations of Brachiomonas submarina was low $(<2.5 \%)$, and clearly lower than that in filtered sea water (ca $26 \%$ ) (Fig. 3,
Table 2). With low concentrations of non-toxic Nodularia sp., mortality was comparable to that in filtered sea water ( 20 to $30 \%$ ); however, in the 2 highest concentrations mortality was low ( 2 to $6 \%$ ), and not significantly different from mortality with B. submarina in corresponding concentrations (Tukey HSD; $p>0.05$ ). In contrast, mortality with toxic Nodularia sp. was always higher than that in the filtered sea water (40 to $70 \%$ ), and significantly different from mortality with $B$. submarina in corresponding concentrations (Tukey HSD; $p<0.05)$. In mixture experiments, almost no mortality was observed; only in the $8: 1$ toxic Nodularia sp. $+B$. submarina treatment was mortality elevated.

\section{Carbon and nitrogen content}

Carbon content of copepods measured at the end of the experiments was variable $\left(2\right.$ to $4 \mu \mathrm{g} \mathrm{C}$ ind. ${ }^{-1}$ ); generally carbon content of individuals fed with Brachiomonas submarina was higher than that of copepods fed with Nodularia sp. or that of starved individu-

Table 3. Eurytemora affinis. Hatching success (mean \pm standard deviation) of eggs (\% per experiment), produced in experiments or produced in natural food conditions and exposed to different concentrations of experimental algae (Field). Number of eggs in hatching experiments and number of replicate experiments (n) are indicated. -: missing values, blanks: no experiments; other abbreviations as in Table 1

\begin{tabular}{|c|c|c|c|c|c|c|c|}
\hline Algae & $\begin{array}{c}\text { Conc. } \\
\left(\mu \mathrm{g} \mathrm{C}^{-1}\right)\end{array}$ & $\begin{array}{l}\text { Exp } \\
\text { No. of eggs }\end{array}$ & $\begin{array}{l}\text { eriment } \\
\text { Hatching }(\%)\end{array}$ & n & $\overline{\text { No. of eggs }}$ & $\begin{array}{l}\text { Field } \\
\text { Hatching }(\%)\end{array}$ & $n$ \\
\hline FW & 0 & $14-50$ & $41 \pm 45$ & 7 & $109-110$ & $96 \pm 3.7$ & 2 \\
\hline \multirow[t]{4}{*}{$\mathrm{Br}$} & 50 & $20-105$ & $29 \pm 51$ & 3 & 111 & $77+23$ & 2 \\
\hline & $\begin{array}{l}100 \\
200\end{array}$ & $\begin{array}{c}170 \\
20-135\end{array}$ & $\begin{array}{c}78 \\
49 \pm 69\end{array}$ & $\begin{array}{l}1 \\
2\end{array}$ & - & $100 \pm 0$ & 2 \\
\hline & 400 & $62-169$ & $70 \pm 0.8$ & 3 & $141-156$ & $73 \pm 2.7$ & 2 \\
\hline & 600 & 216 & 78 & 1 & & & \\
\hline \multirow[t]{5}{*}{$N$} & 50 & $18-24$ & $42 \pm 36$ & 3 & $77-87$ & $88 \pm 10$ & 2 \\
\hline & 100 & 15 & 0 & 1 & & & \\
\hline & 200 & $15-18$ & $34 \pm 34$ & 3 & $93-113$ & $87 \pm 13$ & 2 \\
\hline & 400 & $18-67$ & $56 \pm 49$ & 3 & 107 & $92 \pm 6.1$ & 2 \\
\hline & 600 & 94 & 87 & 1 & & & \\
\hline \multirow[t]{5}{*}{ Nt } & 50 & $<10$ & - & - & $78-125$ & $100 \pm 0$ & 2 \\
\hline & 100 & 18 & 0 & 1 & & & \\
\hline & 200 & $18-20$ & $0 \pm 0$ & 3 & 82 & $90 \pm 9.8$ & 2 \\
\hline & 400 & $30-50$ & $0 \pm 0$ & 2 & $26-47$ & $36 \pm 13$ & 2 \\
\hline & 600 & 115 & 0 & 1 & & & \\
\hline \multicolumn{2}{|c|}{$\mathrm{Br}+\mathrm{N} 200+200$} & 141 & 69 & 1 & & & \\
\hline \multicolumn{2}{|c|}{$\mathrm{Br}+\mathrm{Nt} 200+200$} & 147 & 58 & 1 & & & \\
\hline \multicolumn{2}{|c|}{$\mathrm{Br}+\mathrm{N} \quad 400+50$} & 50 & 51 & 1 & & & \\
\hline \multicolumn{2}{|c|}{$\mathrm{Br}+\mathrm{Nt} 400+50$} & 57 & 75 & 1 & & & \\
\hline \multicolumn{2}{|c|}{$\mathrm{Br}+\mathrm{N} 50+400$} & & & & & & \\
\hline \multicolumn{2}{|c|}{$\mathrm{Br}+\mathrm{Nt} 50+400$} & & & & & & \\
\hline
\end{tabular}



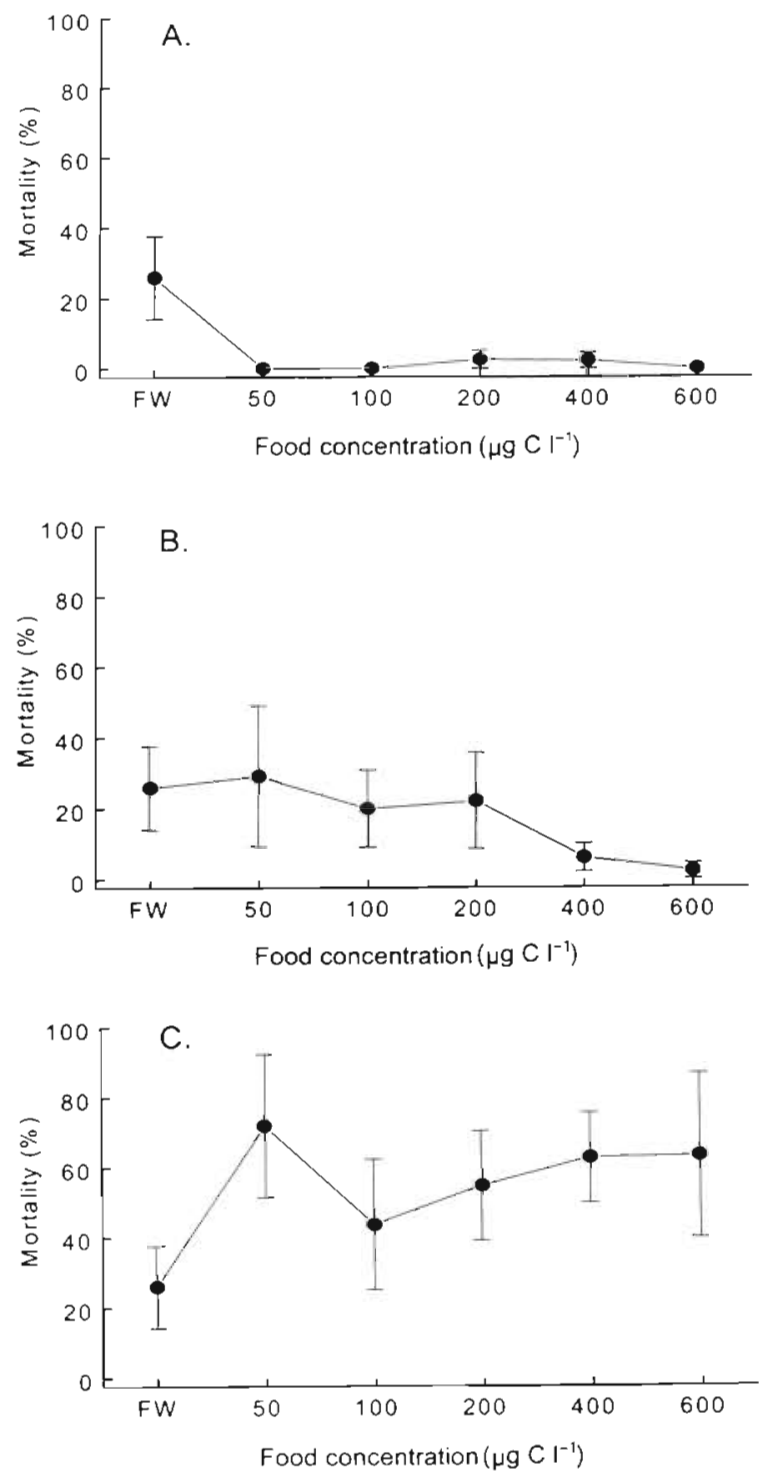

Fig. 3. Eurytemora affinis. Mortality (\%) in experiments with different concentrations of (A) Brachiomonas submarina. (B) non-toxic Nodularia sp., and (C) toxic Nodularia sp. Data denote means and vertical bars denote standard errors. $n=3$ to 5 (FW: filtered sea water)

als (Fig. 4). Also, carbon content of copepods fed with $B$. submarina increased during the experiment if compared to carbon content of field individuals. However, the differences in carbon content between treatments were not statistically significant (1-way ANOVA; df = $10, F=1.421, \mathrm{p}>0.05)$.

Differences in copepod nitrogen content between treatments were generally similar to differences in carbon content, and not significantly different from each other ( 1 -way ANOVA; $\mathrm{df}=10, F=0.904, \mathrm{p}>0.05$ ). The average nitrogen content of copepods varied between 0.5 and $0.9 \mu$ ind. $^{-1}$ (Fig. 4).
Carbon
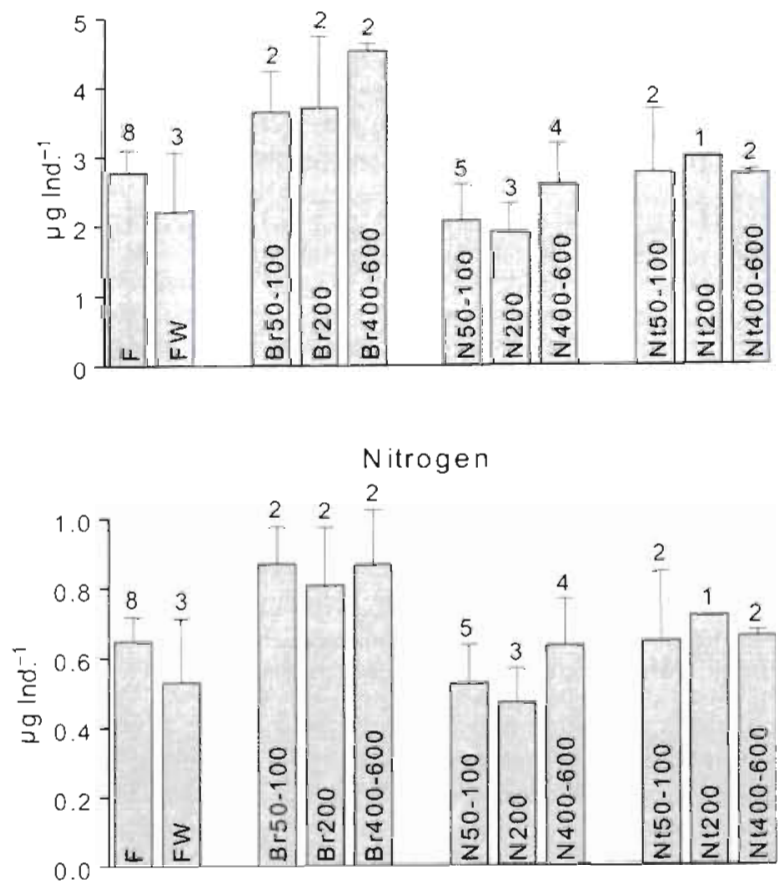

$\mathrm{C}: \mathrm{N}$

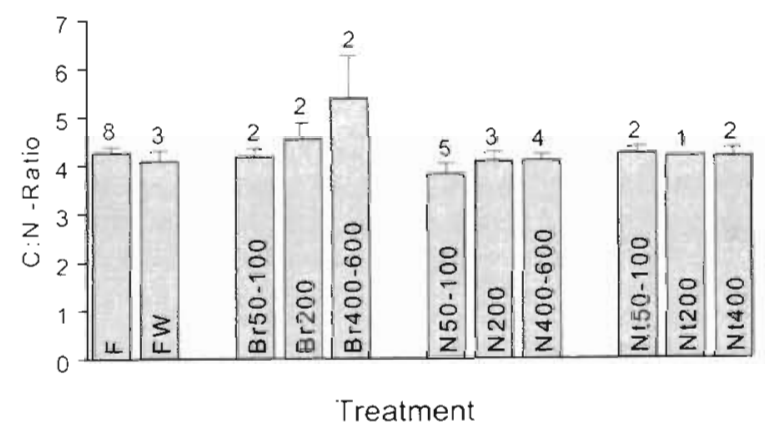

Fig. 4. Eurytemora affinis. Mean carbon and nitrogen content ( $\mu \mathrm{g}$ ind. ${ }^{-1}$ ) and $\mathrm{C}: \mathrm{N}$ ratio of copepods exposed to different concentrations $\left(50-100,200,400-600 \mathrm{\mu g} \mathrm{Cl}^{-1}\right)$ of Brachiomonas submarina and non-toxic and toxic Nodularia sp. Error bars denote standard errors. Number of replicate measurements indicated above each bar. Field $(F)$ : individuals collected from the sea at the beginning of each experiment; other abbreviations as in Fig. 2

In contrast to variable carbon and nitrogen contents, the C: $\mathrm{N}$ ratio of copepods was relatively stable, from 4 to 5 (Fig. 4), and differed significantly between treatments ( 1 -way ANOVA; df $=10, F=2.492, p<0.05$ ). With 400 to $600 \mu \mathrm{g} \mathrm{C} \mathrm{l}^{-1}$ of Brachiomonas submarina the $\mathrm{C}: \mathrm{N}$ ratio was significantly higher than that of the field copepods (Tukey HSD; $\mathrm{p}<0.05$ ). In general, the $\mathrm{C}: \mathrm{N}$ ratio of Eurytemora affinis was lower than what is reported in the literature for high-latitude marine planktonic copepods (Gismervik 1997). 


\section{DISCUSSION}

The calanoid copepod Eurytemora affinis was not able to reproduce on a diet of the cyanobacterium Nodularia sp., irrespective of the toxicity of the Nodularia sp. strain. Thus, the nutritional quality of Nodularia sp. was not high enough to support egg production, which is in agreement with previous findings (Sellner et al. 1996, Schmidt \& Jónasdóttir 1997). In contrast, non-toxic Nodularia sp. did support maintenance, even though the concentration needed was high ( 400 to $600 \mathrm{\mu g} \mathrm{C}^{-1}$ ): if compared to Brachiomonas submarina as a food source, a similar survival rate was obtained already at the lowest concentration offered, $50 \mu \mathrm{g} \mathrm{C} \mathrm{l}^{-1}$. This is in agreement with the study of Sterner \& Robinson (1994), suggesting that the food quality required for maintenance is lower than that needed for growth and that, with low-quality food, threshold food levels are likely to be high. This was also suggested by the increase in carbon and nitrogen content of copepods fed with B. submarina, compared to low carbon and nitrogen content of individuals fed with non-toxic Nodularia sp. It seemed that individuals fed B. submarina had food in excess and were able to build up reserve materials (such as lipids), whereas individuals fed with non-toxic Nodularia sp. needed all food to support maintenance. In contrast, the survival of copepods with the toxic Nodularia sp. only decreased with increasing food concentration, which indicated a strong toxic effect of nodularin on copepods. Average effects of Nodularia sp. and other species of cyanobacteria on growth, reproduction and survival of aquatic crustaceans in the literature and in this study are summarised in Table 4 .

The reproductive success of copepods is not only dependent on egg production, but also on egg viability, which may not be affected by food quality in the same manner as egg production is affected (Ianora \& Poulet 1993). Since certain food species can induce high egg production, but be detrimental to the hatching success of eggs (e.g. the diatom Thalassiosira rotula; Ianora \& Poulet 1993, Chaudron et al. 1996), the

Table 4. Summary of the average effects of cyanobacteria on reproduction (egg production and hatching success), growth and survival of aquatic crustaceans from the literature and based on the present study. ( + : positive response; -: negative response; 0 : no response [in mixtures]. 'Species or strains with detected toxins; Ep: egg production)

\begin{tabular}{|c|c|c|c|c|c|c|}
\hline Cyanobacteria & Ep & Hatching & Growth & Survival & Crustacean & Source \\
\hline \multicolumn{7}{|l|}{ Freshwater studies } \\
\hline Microcystis aeruginosa" & - & - & - & - & Daphnia spp. & $\begin{array}{l}\text { Reinikainen et al. (1994, 1995), } \\
\text { Hietala et al. (1995) }\end{array}$ \\
\hline M. aeruginosa & - & & & + & $\begin{array}{l}\text { Achantocyclops } \\
\text { robustus }\end{array}$ & Vasconcelos (1990) \\
\hline Aphanizomenon flos-aquae & - & & - & - & D. pulex & Holm \& Shapiro (1984) \\
\hline Oscillatoria limnetica & + & & + & & Daphnia spp. & Repka $(1996,1997)$ \\
\hline Anabaena oscillarioides & + & & + & + & Boeckella spp. & Xu \& Burns (1991), Burns \& Xu (1990b) \\
\hline Anabaena flos-aquae & + & & - & + & Boeckella spp. & Xu \& Burns (1991), Burns \& Xu (1990b) \\
\hline Nostoc sp. & + & & - & + & Boeckella spp. & Xu \& Burns (1991), Burns \& Xu (1990b) \\
\hline Nostoc calcicola & - & & - & - & Boeckella spp. & Xu \& Burns (1991), Burns \& Xu (1990b) \\
\hline $\begin{array}{l}\text { Anabaena flos-aquae }+ \\
\text { Cryptomonas }\end{array}$ & + & & - & 0 & $\begin{array}{l}\text { Boeckella } \\
\text { triarticulata }\end{array}$ & Twombly et al. (1998) \\
\hline $\begin{array}{l}\text { Synecococcus elongatus }+ \\
\text { P-limited Schenedesmus spp. }\end{array}$ & + & & + & & Daphnia spp. & DeMott (1998) \\
\hline \multicolumn{7}{|c|}{ Brackish water and marine studies } \\
\hline Nodularia spumigena & - & & & & $\begin{array}{l}\text { Acartia bifilosa } \\
\text { Eurytemora affinis }\end{array}$ & Sellner et al. (1996) \\
\hline Aphanizomenon flos-aquae & - & & & & $\begin{array}{l}\text { A. bifilosa } \\
\text { E. affinis }\end{array}$ & Sellner et al. (1996) \\
\hline Nodularia sp. & - & - & & + & E. affinis & Present study \\
\hline Nodularia sp." & - & - & & - & E. affinis & Present study \\
\hline $\begin{array}{l}\text { Nodularia sp. + Brachiomonas } \\
\text { submarina }\end{array}$ & - & 0 & & 0 & E. affinis & Present study \\
\hline Microcystis aeruginosa & - & & & & Acartia tonsa & Schmidt \& Jónasdóttir (1997) \\
\hline Nodularia spumigena & - & & & & A. tonsa & Schmidt \& Jónasdóttir (1997) \\
\hline $\begin{array}{l}\text { M. aeruginosa }+ \\
\text { Thalassiosira weissflogii }\end{array}$ & + & & & & A. tonsa & Schmidt \& Jónasdóttir (1997) \\
\hline N. spumigena $+T$ weissflogii & 0 & & & & A. tonsa & Schmidt \& Jónasdóttir (1997) \\
\hline
\end{tabular}


quality of alga species as copepod food should not be evaluated based on egg production alone. Food quality may affect the hatching success negatively either by inhibitory compounds or by inadequate nutrition (Poulet et al. 1994, Guisande \& Harris 1995, Miralto et al. 1998). In this study we observed both effects. Insufficient food (either quantity or quality) was probably the reason for low hatching success and production of deformed egg-sacs in filtered sea water, and with low concentrations of Brachiomonas submarina and nontoxic Nodularia sp. In contrast, with toxic Nodularia sp. the reproductive success of copepods did not increase with increasing food concentration but hatching success was always zero, suggesting the effect of inhibitory compounds. Thus, beside some diatom species (Poulet et al. 1995, Chaudron et al. 1996), cyanobacteria can also produce compounds which inhibit the hatching success of copepod eggs.

The hatching success of eggs was more dependent on the food conditions during the production of eggs than on the quality of media surrounding the eggs, since the hatching success of eggs produced in natural food conditions was generally high, irrespective of food species or concentrations to which the eggs were exposed. This suggests that the negative effect on egg hatching is mediated via accumulation of toxins in the female, and subsequent inhibition or disturbance of embryogenesis, similar to the studies of inhibitory effects of diatoms on hatching success (e.g. Chaudron et al. 1996). However, very high concentration of toxic Nodularia sp. also did decrease hatching success of eggs produced in natural food conditions, probably due to direct toxic effects of cell exudates on eggs. Thus, inhibitory compounds of toxic cyanobacteria may affect hatching success even if copepods would selectively avoid feeding on these species.

Similar to the study of Schmidt \& Jonasdóttir (1997), Nodularia sp. did not increase reproduction of Eurytemora affinis when offered in mixtures with Brachiomonas submarina. Generally, if a food species is toxic, resistant to digestion, not ingested or does not add to the nutritional quality of the other food species, no beneficial effect can be expected in mixtures. We assumed that neither toxicity nor low ingestion of Nodularia sp. affected the result in mixtures with $B$. submarina and non-toxic Nodularia sp. Even though Nodularia sp. may produce toxic substances other than nodularin (cf. Nizan et al. 1986, Jungmann 1992), this was not likely to have occurred in our experiments, since mortality of copepods fed with a substantial amount of the non-toxic (nodularin-deficient) Nodularia sp. strain was low. Further, since $E$. affinis ingests non-toxic Nodularia sp. if it is offered as the sole food (J. Engström, M. Koski, M. Viitasalo, M. Reinikainen, S. Repka, K. Sivonen unpubl.), we assume that it was also ingested in mixtures, especially if the concentration of the other food species was below the saturation level of feeding (as was the case in experiments with 50 or $200 \mu \mathrm{g} \mathrm{C} \mathrm{l}^{-1}$; cf. Kiørboe et al. 1985). We conclude that Nodularia sp. did not add to the quality of $B$. submarina as food for $E$, affinis, which is in contrast with the study of Schmidt \& Jonasdóttir (1997), who found that the cyanobacterium Microcystis aeruginosa did supplement a diatom diet. Possibly the limiting factor for egg production both in green algae and cyanobacteria is the same, e.g. long-chain polyunsaturated fatty acids, which are scarce in both groups of algae (Ahlgren et al. 1992, Dunstan et al. 1994). This could explain why the addition of cyanobacteria did not have a positive effect in our experiments similar to observations by Schmidt \& Jónasdóttir (1997). However, Nodularia sp. may still have beneficial effects on other lifehistory parameters, such as number of clutches produced per female or individual age (Twombly et al. 1998), which were not included in the present study.

No increased mortality was observed in most of the mixture experiments, which indicated that Nodularia sp. did not excrete a large amount of toxins into the water and that copepods were able to avoid ingesting large amounts of toxic Nodularia sp., when offered together with Brachiomonas submarina. Also, no deformed egg-sacs were observed in any of the mixture experiments, and hatching success was generally high. However, hatching success was not measured in the mixtures with high concentration of Nodularia sp. In contrast, we did observe some inhibitory effects of Nodularia sp. on copepod reproduction; the egg production of Eurytemora affinis was in most cases (with the unexplained exception of the 1:1 mixture of $B$. submarina and non-toxic Nodularia sp.) lower in mixtures than with $B$. submarina alone. It is possible that Nodularia sp. filaments decreased copepod feeding efficiency on B. submarina, and thus egg production, even though no direct toxic effects were observed.

In conclusion, non-toxic cyanobacteria can be used as an energy source, even though they probably lack some nutritional components essential for growth or reproduction. This is in agreement with previous studies; while there are very few reports on successful reproduction with cyanobacteria as a food source, some studies do show growth or survival on a pure (non-toxic) cyanobacterial diet. In contrast, toxic species induce elevated mortality (at least if ingested), and may have detrimental effects on the hatching success of eggs, and thus generally cannot be used by crustaceans (Table 4 ).

Our results indicated that Eurytemora affinis is able to survive, but not to reproduce, in mono-specific Nodularia sp. blooms, if the strain is non-toxic. In contrast, if the bloom is toxic, the mortality rate of E. affinis 
is likely to be higher than that of starved individuals. However, in more natural conditions, when other food species are also available, E. affinis seems to be able to avoid ingesting toxic Nodularia sp., and thus survives and produces eggs, the viability of which depends on the concentration of toxic or inhibitory substances in the water. These results indicate that $E$. affinis may be able to survive during cyanobacterial blooms better than the other common copepod species Acartia bifilosa, which does not even ingest non-toxic Nodularia sp. filaments (J. Engström, M. Koski, M. Viitasalo, M. Reinikainen, S. Repka, K. Sivonen unpubl.) and which has a high mortality rate in the presence of toxins (M. Reinikainen, S. Repka, M. Wahlsten, K. Sivonen unpubl.).

Such differential effects of cyanobacteria on different zooplankton species are well known from freshwater studies (e.g. Gilbert 1990, DeMott et al. 1991). However, for brackish and marine environments data are scarce on the interactions between cyanobacteria and mesozooplankton. In our opinion, more studies are needed to reveal the relationship between different species and life-stages of marine or brackish water copepods and cyanobacteria, to be able to estimate the effect of cyanobacterial blooms on mesozooplankton community structure. Further, more studies are needed to reveal the mechanism behind the negative effect of cyanobacteria on the hatching success of copepod eggs.

Acknowledgements. We wish to thank S. Repka, U. Sjolund and $\mathrm{S}$. and $\mathrm{G}$. Hällfors for the help with algal cultures and $\mathrm{A}$. Nevalainen for running the C: $\mathrm{N}$ analysis. Nodularia sp. cultures originated from the culture collection of K. Sivonen at the Department of Applied Chemistry and Microbiology, University of Helsinki. M. Järvinen, M. Reinikainen, S. Repka and 4 anonymous referees gave helpful comments on earlier drafts of the manuscript. This study was financed by the Maj and Tor Nessling Foundation, Walter and Andree de Nottbeck foundation and Academy of Finland

\section{LITERATURE CITED}

Ahlgren G, Gustafsson IB, Boberg M (1992) Fatty acid content and chemical composition of freshwater microalgae. J Phycol 28:37-50

Andersen CM, Nielsen TG (1997) Hatching rate of the eggcarrying estuarine copepod Eurytemora affinis. Mar Ecol Prog Ser 160:283-289

Arnold DE (1971) Ingestion, assimilation, survival, and reproduction by Daphnia pulex fed seven species of blue-green algae. Limnol Oceanogr 16:906-920

Ban S (1994) Effect of temperature and food concentration on post-embryonic development, egg production and adult body size of calanoid copepod Eurytemora affinis. J Plankton Res 16:721-735

Burns CW, Hegarty B (1994) Diet selection by copepods in the presence of cyanobacteria. J Plankton Res 16:1671-1690

Burns CW, Xu Z (1990a) Utilization of colonial cyanobacteria and algae by freshwater calanoid copepods: survivorship and reproduction of adult Boeckella spp. Arch Hydrobiol $117: 257-270$

Burns CW, Xu Z (1990b) Calanoid copepod feeding on algae and filamentous cyanobacteria: rates of ingestion, defaecation and effects on trichome length. J Plankton Res 12 : 201-213

Carmichael WW, Gorham PR (1981) The mosaic nature of toxic blooms of cyanobacteria. In: Carmichael WW (ed) The water environment: algal toxins and health. Plenum, New York, p 161-171

Chaudron Y, Poulet SA, Laabir M, Ianora A, Miralto A (1996) Is hatching success of copepod eggs diatom densitydependent? Mar Ecol Prog Ser 144:185-193

DeMott WR (1998) Utilization of a cyanobacterium and a phosphorus-deficient green alga as complementary resources by daphnids. Ecology 79:2463-2481

DeMott WR, Moxter (1991) Foraging on cyanobacteria by copepods: responses to chemical defences and resource abundance. Ecology 72:1820-1834

DeMott WR, Zhang QX, Carmichael WW (1991) Effects of toxic cyanobacteria and purified toxins on the survival and feeding of a copepod and three species of Daphnia. Limnol Oceanogr 36:1346-1357

Dunstan GA, Volkman JK, Jeffrey SW, Barrett SM (1994) Biochemical composition of microalgae from the green algae classes Chlorophyceae and Prasinophyceae. 2. Lipid classes and fatty acids. J Exp Mar Biol Ecol 161:115-134

Gilbert JJ (1990) Differential effects of Anabaena affinis on cladocerans and rotifers: mechanisms and implications. Ecology 71:1727-1740

Gismervik I (1997) Stoichiometry of some marine planktonic crustaceans. J Plankton Res 19:279-285

Guisande C, Harris R (1995) Effect of total organic content of eggs on hatching success and naupliar survival in the copepod Calanus helgolandicus. Limnol Oceanogr 40: $476-482$

Gulati RD, Siewertsen K, van Liere L (1991) Carbon and phosphorus relationships of zooplankton and its seston food in Loosdrecht lakes. Mem Ist Ital Idrobiol Dott Marco Marchi $48: 279-298$

Hällfors G, Hällfors S (1992) The Tvärminne collection of algal cultures. Tvärminne Stud 5:15-17

Hietala J, Reinikainen M, Walls M (1995) Variation in life history responses of Daphnia to toxic Microcystis aeruginosa. J Plankton Res 17:2307-2318

Hirche HJ (1992) Egg production of Eurytemora affiniseffect of k-strategy. Estuar Coast Shelf Sci 35:395-407

Holm NP, Shapiro J (1984) An examination of lipid reserves and the nutritional status of Dapnia pulex fed Aphanizomenon flos-aquae. Limnol Oceanogr 29:1137-1140

Ianora A, Poulet S (1993) Egg viability in the copepod Temora stylifera. Limnol Oceanogr 38:1615-1626

Infante A, Abella SEB (1985) Inhibition of Daphnia by Oscillatoria in Lake Washington. Limnol Oceanogr 30:1046-1052

Jungmann D (1992) Toxic compounds isolated from Microcystis PCC7806 that are more active against Daphnia than two microcystins. Limnol Oceanngr 37:1777-1783

Kiørboe T, Sabatini M (1995) Scaling of fecundity, growth and development in marine planktonic copepods. Mar Ecol Prog Ser 120:285-298

Kiørboe T, Møhlenberg F, Hamburger K (1985) Bioenergetics of the planktonic copepod Acartia tonsa: relation between feeding, egg production and respiration, and composition of specific dynamic action. Mar Ecol Prog Ser 26:85-97

Kirk KL, Gilbert JJ (1992) Variation in herbivore response to 
chemical defences: zooplankton foraging on toxic cyanobacteria. Ecology 73:2208-2217

Kononen K, Kuparinen J, Mäkelä K, Laanemets J, Pavelson J Nōmmann S (1996) Initiation of cyanobacterial blooms in a frontal region at the entrance to the Gulf of Finland Baltic Sea. Limnol Oceanogr 41:98-112

Koski M, Viitasalo M. Kuosa H (1999) Seasonal development of mesozooplankton biomass and production on the SW coast of Finland. Ophelia 50:69-91

Lampert W (1981) Inhibitory and toxic effects of blue-green algae on Daphnia. Int Rev Gesamten Hydrobiol 66 285-298

Lampert W (1987) Laboratory studies on zooplankton-cyanobacteria interactions. N Z J Mar Freshw Res 21:483-490

Lehtimäki J, Sivonen K, Luukkainen R, Niemelä J (1994) The effects of incubation time, temperature, light, salinity, and phosphorus on growth and hepatotoxin production by Nodularia strains. Arch Hydrobiol 130:269-282

Miralto A, Ianora A, Guglielmo L, Zagami G, Buttino I (1998) Egg production and hatching success in the peri-Antarctic copepod Calanus simillimus. J Plankton Res 20:2369-2378

Montagnes DJS, Berges JA, Harrison PJ, Taylor FJR (1994) Estimating carbon, nitrogen, protein, and chlorophyll a from volume in marine phytoplankton. Limnol Oceanogr 39:1044-1060

Müller-Navarra D (1995) Evidence that a highly unsaturated fatty acid limits Daphnia growth in nature. Arch Hydrobiol 132:297-307

Nizan S, Dimentman C, Shilo M (1986) Acute toxic effects of cyanobacterium Microcystis aeruginosa on Daphnia magna. Limnol Oceanogr 31:497-502

Porter KG, Orcutt GD (1980) Nutritional adequacy, manageability, and toxicity as factors that determine food quality of green and blue-green algae for Daphnia. Am Soc Limnol Oceanogr Spec Symp 3:268-281

Poulet SA, Ianora A, Miralto A, Meijer L (1994) Do diatoms arrest embryonic development in copepods? Mar Ecol Prog Ser 111:79-86

Rapala J, Sivonen K, Luukkainen R, Niemelä I (1993) Anatoxin-a concentration in Anabaena and Aphanizomenon under different environmental conditions and comparison of growth by toxic and non-toxic Anabaena-strains-a laboratory study. J Appl Phycol 5:581-591

Reinikainen M, Ketola M, Walls M (1994) Effects of concentrations of toxic Microcystis aeruginosa and an alternative food on the survival of Daphnia pulex. Limnol Oceanogr 39:424-432

Reinikainen M, Ketola M, Jantunen M, Walls M (1995) Effects

Editorial responsibility: Otto Kinne (Editor),

Oldendorf/Luhe, Germany of Microcystis aeruginosa exposure and nutritional status on the reproduction of Daphnia pulex. J Plankton Res 17: $431-436$

Repka S (1996) Inter- and intraspecific differences in Daphnia life histories in response to two food sources: the green alga Scenedesmus and the filamentous cyanobacterium Oscillatoria. J Plankton Res 18:1213-1223

Repka S (1997) Effects of food type on the life history of Daphnia clones from lakes differing in trophic state. I. Daphnia galeata feeding on Scenedesmus and Oscillatoria. Freshw Biol 37:675-683

Richardson K (1997) Harmful or exceptional phytoplankton blooms in the marine ecosystem. Adv Mar Biol 31:302-383

Schmidt K, Jónasdóttir SH (1997) Nutritional quality of two cyanobacteria: how rich is 'poor' food? Mar Ecol Prog Ser 151:1-10

Sellner KG (1997) Physiology, ecology, and toxic properties of marine cyanobacteria blooms. Limnol Oceanogr 42: $1089-1104$

Sellner KG, Olson MM, Kononen K (1994) Copepod grazing in a summer cyanobacteria bloom in the Gulf of Finland. Hydrobiologia 292/293:154-249

Sellner KG, Olson MM, Olli K (1996) Copepod interactions with toxic and non-toxic cyanobacteria from the Gulf of Finland. Phycologia 35:177-182

Sivonen K, Kononen K, Carmichael WW, Dahlem AM, Rinehart KL, Kiviranta J, Niemelä SI (1989) Occurrence of the hepatotoxic cyanobacterium. Nodularia spumigena in the Baltic Sea and structure of the toxin. Appl Environ Microbiol 55:1990-1995

Sterner RW, Robinson JL (1994) Thresholds for growth in Daphnia magna with high and low phosphorus diet. Limnol Oceanogr 39:1228-1232

Turner JT, Tester PA (1997) Toxic marine phytoplankton, zooplankton grazers, and pelagic food webs. Limnol Oceanogr 42:1203-1214

Twombly S, Clancy N, Burns CW (1998) Life history consequences of food quality in the freshwater copepod Boeckella triarticulata. Ecology 79:1711-1724

Vasconcelos VM (1990) Preliminary results of a study on the impact of toxic and nontoxic cyanobacteria on some freshwater microcrustacean species. Crustaceana 59:316-318

Viitasalo M, Vuorinen I, Saesmaa S (1995) Mesozooplankton dynamics in the northern Baltic Sea: connections with hydrography and weather. J Plankton Res 17:1857-1878

Xu Z, Burns CW (1991) Development, growth and survivorship of juvenile calanoid copepods on diets of cyanobacteria and algae. Int Rev Gesamten Hydrobiol 75:73-87

Submitted: January 15, 1999; Accepted: March 29, 1999

Proofs received from author(s): August 25, 1999 